\title{
Federalism and the Creation of Sub-national States in Nigeria: Appraising the State-Creation Exercise under Babangida Administration
}

\author{
Abdul-Majeed Alkali (PhD) \\ Department of Political Science, Usmanu Danfodiyo University Sokoto, Nigeria.
}

\begin{abstract}
The territorial boundaries of the Nigerian federation have undergone frequent changes under military regimes. From 1967, the structure of the federation has been reconstituted five times. The paper seeks to appraise the state-creation exercises under Babangida Administration, with a view to explaining the factors and forces which may have influenced the creation of the 21 - and the 30-state federal structures in Nigeria. The unrelenting pressure for the creation of additional subnational units in Nigeria is a function of the competition amongst federating ethnic groups in the country for favourable allocation of distributive federal resources. Indeed, the insatiable distributive appetite of state proposers would explain why, in spite of the creation of the 36- state federal structure in 1996 the calls for more states have not abated in Nigeria.
\end{abstract}

Key words: Agitation; Federalism; Pressures; Restructuring; States.

\section{INTRODUCTION}

The creation of sub-national states is a structural response to the imperatives of governance in federal polities. For instance, in the United States while "almost all the other states have been constituted from territory that has first been administered by the federal government or, in the case of the original thirteen, by the colonial government," one state (West Virginia) was created out of another state. In Canada, general stability in provincial boundaries notwithstanding, Quebec and Ontario were created in 1867 as separate provinces out of the United Canada Province, vide the British North America Act. While the Swiss Cantons have not been subject to sub-division, Jura Canton had to be created after a violent campaign. In response to separatist agitation, India has had to create twenty-five states and seven union territories (Dent 1995: p. 130). As a territorial federation, Nigeria embarked on state reorganisation and creation. What is unique in the case of Nigeria is the frequency with which the constituent units of the federation have been created. As Suberu succinctly puts it, "a striking, yet sobering feature of Nigerian politics has been the severe instability in the internal territorial configuration of the country's federal system" (Suberu 1988: p.276). The territorial boundaries of the federation have been severally transformed. A series of state-creation exercises brought about a federation of 12 states in 1967; 19 states in 1976; 21 states in 1987; 30 states in 1991 and 36 states in 1996. State creation in other federal polities would not be characterised by the same frequency. Indeed, as Dent observes, only India "has experienced the same extreme pressure as Nigeria for the creation of new states" (Dent 1995: p.130).

In both Nigeria and India, the state has emerged as the epi-center of polities. In Nigeria, state creation came to be viewed not as an antidote against political marginalisation (as it was previously understood), but as an avenue for acquiring political power. State creation came to be looked on faviourably for the simple reason that "it gave increased representation for their supporters in the senate and also a larger share of revenue allocated from the federal government, partly on a basis of population, but partly on a basis of equality [of] states" (Dent 1995: p.133). With regards to India, Shastri observes "[s]tates have today emerged as the focal point of Indian politics and have significantly influenced the nature and course of federal politics" (Shastri 2001: p.9).India, which became a federation in 1950, reorganised "the structure of its federation in order to satisfy the numerous politically pressing linguistic particularism of its people, beginning from 1956, but which, today, has brought about a federation of 25 states" (Akindele 1996: p.14). But, Nigeria, today, has a 36-state federal structure. What is more, there are still pressures for the creation of more sub-national units.

In contradistinction with other contemporary federations, Nigeria would appear to have far too many states. According to Akindele (1996: p.13):

[t]he number of the component units in the federal systems today stands as follows: the United States, 50 states (plus 2 federacies), 3 local home-rule territories, 3 unincorporated territories); Australia, 6 states (plus 4 administered territories, 3 territories and 1 capital territory); Canada, 10 provinces (plus 2 territories); Republic of India, 25 states (plus 8 union territories); Malaysia, 13 states; and Switzerland, 26 cantons. There is, of 
course, considerable variation in the size and wealth of these constituent units, which has a telling effect on the politics and operation of specific federations.

State creation is one of the controversial national issues that have featured predominantly in Nigeria's political system. Several works have focused on Nigerian federalism, particularly as it relates to territorial politics (among others Elaigwu 1978, 1979, 1983, 1994a, 1994b, 1996; Jinadu 1987; Tagowa 1994; Eleazu 1997; Odenigwe 1977; Amuwo 1998; Ukwu 1987; Nwabueze 1983; Awa 1964, 1955; Smith 1977; Worrall 1965; Tamuno 1970; Osaghae 1985; Smith 1987; Nnoli 1978; Ekekwe 1986; Yahaya 1978; Yaqub 1997; Bayero 1990; Kumo 1994; Gana 1987; Suberu 1994, 1998; Adejuyigbe 1979; Asobie 1996; Dare 1979; Ellah 1983; Faruk 1992).

A unique feature of Nigerian federalism is the fact that the structural transformation of the Nigerian federation was effected by the military. The military occupies a central position in Nigerian politics by virtue of its domination of the political arena. In Nigeria, military rule would appear to be the vogue rather than an aberration, given the fact that of Nigeria's first twenty-one years of sovereign statehood, the military was in power for thirteen years. Thus, the various state creation exercises - with the inception of the 12 state structure in 1967 to the present 36-state structure - were solely undertaken by the military. One may wish to ask as to why this is so. The reason for this is obvious.It has not been easy to create states under civilian dispensation; infact,the only time that a sub-national unit was created by a civilian government was in 1963, when the MidWest Region was carved out of the defunct Western Region. The process of creating states under civilian administrations would be saddled with constitutional bottlenecks. Given the fact that with every state creation there are always proponents as well as opponents, the opposing political interests would make such an exercise difficult to materialise.

In contrast, military regimes do not take recourse to constitutional stipulations in creating states. Constitutional niceties do not obstruct them, as constitutions would usually be jettisoned under military rule. They are, as it were, at liberty to decree states into existence when the need arises.

This paper seeks to appraise the territorial restructuring of the Nigerian federation by the Babangida military regime. Specifically, the paper seeks to discuss the political dynamics that were involved in the process of state creation under the Babangida era. General Babangida's approach to state creation standsbut as unique amongst his colleagues (military heads of state) some of whom also created states. This is the singular military regime that created states twice; first, in 1987, which ushered the 21-state federal structure and, later, in 1991, when the 30-state federal structure was instituted. The central question to address is: what political considerations informed the creation of the two sets of states?

The paper is structured into seven sections, including this introduction. Section two comprises the frame of analysis. Section three is a brief discussion on the Nigerian federal system. Section four is a background to states creation by Babangida regime. Section five focuses on the 21-state federal structure. Section six centres on the 30 -state federal structure, while section seven is the conclusion.

\section{Frame of Analysis}

The issue of state creation in Nigeria has defied definitive solution. This is because the more new states are created, the more would be the pressing demands for the creation of additional sub-national units. The agitation for states in Nigeria has a very long history; infact, it predates the 1914 amalgamation (see Tamuno 1970). The demands for separate regions by the minority ethnic groups prior to Nigeria's independence prompted the set up of the Henry Willink led Minorities Commission in 1957. The commission was constituted with the objective of inquiring into the fears expressed by the minorities and allaying such fears. The failure of the commission to recommend the creation of additional regions/states in the country precipitated a series of political crises prior to, and immediately after independence.

The call for the territorial restructuring of the Nigerian federation had never abated. Thus, every regime civilian and military, would be saddled with the issue of state creation. Nigeria today has a 36-state federal structure, but the demands for the creation of additional states have continued ad-infinitum. The pressure for state creation would be heightened by the keen competition amongst the federating ethnic groups in Nigeria for political resources, such as "power, influence, authority, leadership positions, representativeness, economic goods and services, decision-making autonomy, security, cultural autonomy, and categoric or relative group equality" (Anise 1979: p. 316).

Seberu (1998) suggests that "distributive pressures lie at the roots of the clamour for new subnational units in Nigeria." He observes that the Nigerian federal system explicitly legitimates and accommodates sectional-territorial constituencies, and thus "provides the structural and institutional framework for the organisation and mediation of the ethnic competition for public resources in Nigeria."

Suberu highlights "some key, closely inter-twined features of distributive federalism in Nigeria." First, because national oil revenues constitute the pivot of the Nigerian economy, the financial resources of the federation are concentrated overwhelmingly in the central government. Second, the states and localities lack 
viable sources of revenue of their own. Third, there is, therefore, the tendency for the states and localities to function as no more than conduits for the dissemination of federal resources to subnational populations, and for the representation of the distributive claims of these communities at the centre. And, fourth, the aforementioned role of Nigeria's subnational units as outlets for federal patronage has been reinforced and legitimised by the practice of dividing federal resources and opportunities on an equal basis among the states and among the localities (Suberu 1998: p. 276).

The thrust of Suberu's argument is that "the unrelenting pressures for territorial changes in Nigeria reflect the insatiable pressures by territorial communities for easy access to central (rentier) revenues." He explains further that "while distributive pressures lie at the roots of the clamour for new subnational units in Nigeria, the actual processes and outcomes of territorial reorganisations usually reflect the interests, perceptions, calculations and manipulations of national governing elite" (Suberu 1998: p. 276).

Distributive considerations could be an issue for explaining the persistence, volatility and salience of the state-creation phenomenon in Nigeria. The politics of state creation in Nigeria could be understood within the broad framework of distributive federalism, the state issue being a necessary aspect of the distributive process of the country's federalism. According to Takaya (1996: p. 83), 'distributive federalism' is so called because "the receiving communities also consider such projects as their rightful shares of the federal commonwealth."

\section{THE NIGERIAN FEDERAL SYSTEM}

As a governmental system, federalism seeks to attain the objective of political integration as well as sub-national self-determination. Elazar (1987) has emphasised that the central concern of federalism is to accommodate the heterogeneity of political systems. Wheare, who is generally regarded as the pioneer of the contemporary view of federalism, conceives the federal principle as a constitutional device for dividing powers between the general and regional governments such that each, within a sphere, are co-ordinate and independent (Wheare 1964).

Federalism has been variously defined. Like every other normative concept, federalism lends itself to several definitional interpretations, aside from the Whearean notion. Kotze, for instance, has identified the two (usual) dimensions from which the concept of federalism would be defined; these are the normative or ideological dimension and the constitutional dimension. The normative or ideological view of federalism holds that conflict between people in plural societies arises as a result of their diverse interests. While, on the other hand, the constitutional perspective has to do with the diffusion of power and its constitutional distribution among the general and constituent levels of government (Kotze 1994).

Some writers took issue with Wheare's legalistic definition of federalism. A major shortcoming of the Whearean perspective, it is pointed out, is that it is unnecessarily restrictive and does not take cognisance of other crucial non-institutional variables. Watts, for instance, stresses socio-cultural and political factors as distinguishing characteristics of a federal system. He holds that other aspects of federal systems, such as the effect of political parties, interest groups, political culture and administrative practice have significant impact on intergovernmental relations. He emphasises the notion of 'interdependent,' rather than 'co-operative' federalism, arguing that "intergovernmental relations in federations have always involved not only co-operation but, at the sometime, bargaining, rivalry and even conflict (Watts 1970:p.7). Watts argues, contrary to Wheare's position, that the federalisation process takes different patterns. He maintains that there is no single pure model of federation that is of universal applicability, and that federations have varied and continue to vary in a number of respects (Watts 1996:pp.1-2).

The varying expositions on the federal principle notwithstanding, there would appear to be some consensus on the essential features of a federal system of government. Federalism is a governmental formula aimed at "maintaining unity while also preserving diversity" (Jinadu 1979:p.15), since "it emanates from the desire of people to form a federal union without necessarily loosing their identities" (Elaigwu 1994:p.3). As Kotze aptly observes, most definitions of federalism would concede the fact that the constituent units of a federation aim at attaining "unity rather than uniformity" (Kotze 1994:p.90). Each and every definition of federalism (and by extension, federal government) would border on the notion of unity within diversity, considering that most societies that would feel persuaded to adopt the federal framework would normally be heterogeneous in composition.

Regardless of whether the evolution of Nigerian federalism is on account of colonial imposition or of historical and geographical factors, ${ }^{1}$ the adoption of a federal system in Nigeria was with a view to providing "a framework for national development in a multi-ethnic and multi-religious society, in terms of interethnic and religious accommodation and peaceful coexistence" (Jega 1999: p.196). However, the first step toward the introduction of a federal system was taken in 1944 when, for administrative purposes, the protectorate of Nigeria was divided into three distinct regions: Northern, Western, and Eastern regions. 
Before 1946, Nigeria had been run more or less as a unitary state. The Richards constitution which was arguably a "quasi-federal" constitution, attempted to strike a balance between authority and responsibility, or, what is the same thing, to reconcile the native authority system with a parliamentary system of government. The Macpherson Constitution of 1951 pushed Nigeria further toward a federal direction; the tripartite division of the country was institutionalised and entrenched in the country.

Nigeria became formally a federal polity in 1954. The federation at the time comprised the Northern, Eastern, and Western Regions, in addition to the Federal Territory of the Southern Cameroons. Each of the regions was vested with executive powers, and enjoyed a large measure of autonomy. Having adopted a federalconstitution in 1954, Nigeria has remained essentially a federal polity - the only exceptions being the brief period when Major - General Aguiyi Ironsi made Nigeria a Unitary State through the instrumentality of the infamous Decree (Unification Decree) No. 34 of May 1966, and the brief period when the then Lieutenant Colonel Gowon promulgated the Confederal Decree No. 8 of March 1967.

\section{BACKGROUND TO STATES CREATION BY BABANGIDA REGIME}

Despite its seemingly strong commitment to the state-creation issue, the Mohammed/Obasanjo regime could not decisively resolve the problem of persistent agitation for new subnational units. Infact, General Mohammed's declaration to the effect that his government would not entertain any further requests for more states did not deter agitators for states. On the contrary, proponents of new states tenaciously called for another review of the political structure of the country.

The question of creation of states was one knotty problem that the Shagari led civilian administration had to contend with. States creation was especially popular during the Second Republic, with virtually every politician championing the creation of additional constituent units in their localities. In the event, the country was abuzz with state creation movements. So emotive and compelling was the advocacy for more states that two separate committees on state creation had to be set up in 1982. First to be set up was the House of Representatives Committee on State Creation. The other committee was constituted by the then President Shagari, who considered it his responsibility as the President to try to bring in consensus and understanding, and to project his party's position on the state question.

Interestingly, while several politicians spear-headed the requests for creation of states, some others were deeply opposed to carving out of new administrative units. The state governors were particularly opposed to the creation of new states out of the states in which they were chief executive. As the Second Republic President, Alhaji Shehu Aliyu Usman Shagari once remarked, "state governors, especially, regarded the state as their own empire and opposed any attempt to trim the territorial size of the states. As far as they were concerned, there can be as many states possibly anywhere else, except in their domain."2

As explained earlier, in addition to the House of Representatives committee on state creation, there was also the presidential committee. A17- an inter-party panel, under the chairmanship of vice President Ekwueme, was set up on March 8, 1982 to advise on the merits and modalities for creating new states. The committee reported on April 6, 1982, and even recommended March 15, 1983 as the deadline for creation of states (Shagari 2001: p.273).The executive intervention by Shagari was supposedly to forestall the proliferation of unviable states.

Intense politicking obstructed the creation of states during the Second Republic. Even though the committees on state creation recommended the creation of additional states, it was not possible for the civilian administration to create any new states before it was overthrown in a military putsch in December 1983.

\section{THE CREATION OF THE 21-STATE FEDERAL STRUCTURE}

In spite of the pressing demands, the Buhari led military regime did not create additional states. Two reasons could be adduced for this. First, the regime was rather short-lived, having held power for only twenty months. The other reason could be the regime's position that having a proliferation of states and local governments at the nation's level of development was counter productive. Rather than creation of more states, the regime would prefer to address issues that it considered far more urgent: security and economic resuscitation. $^{3}$

The debate on state creation, which lulled during the Buhari led military rule, reopened after the inauguration of the Political Bureau on January 13, 1986 by General Babangida. The Bureau, under the leadership of Samuel J. Cookey, was set up with the objective of conducting a national debate on the political future of Nigeria. State creation was one of the issues listed by the Bureau for discussion, and it attracted various comments from a cross-section of Nigerians. However, the over-whelming view was that Nigerians were in support of state creation. The issue remained: what states ought to be created, and according to what criteria? The Bureau received specific demands for, and general suggestions on more states. ${ }^{4}$

To the extent that neither the Shagari administration nor the Buhari regime created new states, the Babangida regime could be said to be the most pressured for restructuring after the Mohammed/Obasanjo's. No 
sooner had the "politburo" been instituted to address, among others, the question of more states than floodgates of demands for states were opened. The nation was literally in a state of flux, as unfulfilled requests for states were revived and new ones were articulated.The Babangida led military regime created two new states on September 23,1987; these were Katsina from the north, and Akwa Ibom from the south - whichbrought the federal structure to 21 states. The Babangida administration would appear to have been pre-eminently encouraged in its structural transformation drive by the perceptible mass support of the exercises. Needless to say, the reorganisations were aimed at satisfying distributive pressures, as Suberu would say. The creation of the 21 states satisfied the long-standing demands for the creation of Akwa Ibom and for splitting Kaduna State into two states.In apparent attempt to put an end to the clamourings for more states, General Babangida had stated in his national address, after the creation of the 21 - statestructure: "This administration wishes to emphasise that no further comments or petition... will be tolerated (on state creation) during the period of transition." And, even though the presidential fiat (Decree No. 19 of 1987) that created the new states did not spell out sanctions against defaulters, the administration nonetheless drove home the point that, for it (at the time) the number of states in the country shall remain $21 .^{5}$

\section{THE CREATION OF THE 30-STATE FEDERAL STRUCTURE}

As stated earlier, government had foreclosed the issue of more states while announcing the creation of 21 states.However, considering the heat generated on the state question prior to 1987 and the fact that the "politburo" had recommended no less than six states, the eventual creation of nine additional states would not come as a surprise. That the Babangida government, by its disposition to create more states, intended to preempt the Third Republic politicians was quite obvious. Aspiring politicians had cashed in on the question of more states, promising to acquiesce to the demands if voted into power, in the event that the military did not create new states. The Babangida regime might have seen the need to take the political initiative of creating additional states before the inception of the next civilian dispensation.

The lifting of ban on partisan politics served as an added impetus for votaries of states to renew their call for additional subnational units. Particularly, proposers of such states as Delta Wawa or Enugu, Sardauna and Kogi which had been expressedly recommended by the "politburo" felt short-changed. To that extent, they were determined, more than ever before, to succeed in their quest for separate states of their own. They saw the favourable disposition toward new states by the military government as an opportunity that they must not let slip by. As state advocates lobbied passionately for the excision of their communities from within the former states, and their reconstitution into entirely new states of the federation, the polity became heated up.

That the Babangida regime was spurred by distributive pressures in its state-creation drive need not be over-emphasised. Federating states had become the sole basis for the allocation of resources. Thus, competing blocs would strive to have as much of the states as they possibly could. The prevailing competition between the various segments and ethnic groups came to the fore, as the nation sets to witness the "birth" of a second generation of states under the Babangida government. General Babangida had this to say on the pressure for more states, following the creation of Katsina and Akwa Ibom states:After the creation of Katsina and Akwa Ibom, there was this clamour that there were more states in the north than in the south. May be the Igbos would say that in terms of population they are equal with the Yorubas. So, why should Yorubas have more states than the Igbos, or why should Hausas have more states than the rest? So, again, this brought the need to review...

Primordial sentiments exacerbated as various ethnic groups pressed for the creation of new states in their areas.With respect to the politicking that preceded the creation of the 30 states, General Babangida recalls that:...Soon, we discovered that they would turn it into more states in the north, less states in the south, more Hausa states; more Yoruba states, less Igbo states, and soon. So, we looked at, first of all, the major ethnic group - the Hausas - and created states that you can call Hausas, actually. The same thing: we created more in the east so as to balance with what they have in the southwest. And, the same thing with the minorities, and so on. So that everybody now feels he belongs within the concept of Nigerian federation. ${ }^{7}$ The creation of the 30- state federal structure was announced on August 27, 1991, during the sixth anniversary of the regime. Decree No. 37 of 1991 (state creation and transitional provisions decree) was promulgated to give the new states legal backing. The additional states were: Abia, Delta, Enugu, Osun, Kogi, Taraba, Yobe, Jigawa, and Kebbi.In creating states government would evince sensitivity to distributive pressures emanating from federating groups. For instance, the Igbos particularly felt aggrieved over the non-creation of a single state from their constituency, during the preceding state-creation exercise. They argued that, in contradistinction to the Hausa/Fulani and Yoruba ethnic groups which had four states each, they had only two: Anambra and Imo states. The Igbos had to be eventually appeased by the creation of two additional states: Abia (out of Imo State) and Enugu (out of Anambra state). As would be expected, the creation of the 30 - state federal structure did not satisfy some Nigerians, least of all the politicians who had championed the movements for the creation of unsuccessful states. No sooner was the creation of nine additional states announced by government than the campaign for creation of additional states 
resumed in full swing. The eventual creation of six new states by General Sani Abacha in 1996, which raised the political structure of Nigeria to 36 states, did not douse the embers of agitation for states in the country.

\section{CONCLUSION}

The paper has tried to appraise the politics of state creation as reflected in the state-creation exercises under Babangida Administration. The particular contribution of this paper lies in its specific focus on the Babangida military regime, more so since the regime had the exceptional privilege of creating two generations of states - the 21- and 30- state federal structure. The regime of General Gowon, which created the 12 states in 1967, promised to create a second set of states in 1974 but the regime reneged on its promise. Pressing as the agitation for the creation of new states were the Gowon regime procrastinated on the issue of additional states. The regime was not able to create any new states before its ouster in July 1975.The paper is implicitly comparative, no doubt, especially that it discusses two separate state-creation exercises under a single regime. However, the paper has not delved in detail into the political processes leading to the creation of each the state structures nor has any attempt been made to compare the two state-creation exercises, with a view to appraising the similarities and differences in the evolution of the states. The foregoing discussion points to the tenaciousness of the demands for more states in Nigeria. A decisive solution to the vexed issue of more subnational units would appear elusive. There is, therefore, the need to place a moratorium on state creation in Nigeria. As Yahaya (1978: p.214) cautioned some time back, the nation need not "indulge in an infinite regress, periodically creating new states in response to each new set of grievances."

\section{Notes}

1. See Osuntokun (1979) for the two perspectives on the evolution of Nigerian federalism.

2. Personal interview with the Second Republic President, Alhaji Shehu Aliyu Usman Shagari on $29^{\text {th }}$ September, 2001.

3. In apparent opposition to the creation of additional administrative units in the country, General Muhammadu Buhari had directed that the 781 local governments created during the Second Republic should be reverted to the old ones, that is, 301 local governments.

4. See Report of the Political Bureau, Abuja: Directorate for Social Mobilization (MAMSER) Council Secretariat, 1986.

5. The Federal Military Governemnt was to rescind its decision on non creation of additional states, when within barely a period of four years it created a second generation of states.

6. Personal interview with General Ibrahim Badamasi Babangida on $8^{\text {th }}$ September, 2001.

7. Personal interview with General Ibrahim Badamasi Babangida.

\section{REFERENCES}

[1] Adejuyigbe, O. (1979). 'Rationale and Effect of States Creation with reference to the 19 states, in A.B. Akinyemi et.al. (eds.) Readings on Federalism (Ibadan: University Press).

[2] Akindele, R.A. (1996). 'Nigeria in the Global Market of Experiments in Federalism,' in J.I. Elaigwu and R.A. Akindele (eds.) Foundations of Nigerian Federalism. 1960-1995 (Abuja: National Council on Intergovernmental Relations).

[3] Amuwo, K. (1998). 'Federal Systems: A theoretical Perspective,' in T. Babawale et.al. (eds.) Reinventing Federalism in Nigeria: Issues and Perspectives (Lagos: Friedrich Ebert Foundation).

[4] Anise, L. (1979). Ethnicity and National Integration in West Africa: Some Theoretical Considerations,' in R.L. Hall (ed.) Ethnic Autonomy - Comparative Dynamics: the Americas, Europe and the Developing World (New York: Pergamon Press).

[5] Asobie, A. (1996). 'Centralising Trends in Nigerian Federalism,' in J.I. Elaigwu and R.A. Akindele (eds.) Foundations of Nigerian Federalism: 1960-1995 (Abuja: National Council on Intergovernmental Relations).

[6] Awa, E.O. (1964). Federal Government in Nigeria. Berkeley: University of California Press.

[7] Bayero, S. (1990). 'Geopolitical Structuring and Development in Nigeria,' in I.E.S. Amdi and W. Hinjari (eds.) Party Systems, Democracy and Political Stability in Nigeria (Nigerian Political Science Association).

[8] Dare, L.O. (1979). 'Perspectives on Federalism,' in A.B. Akinyemi et.al. (eds.) Readings on Federalism (Ibadan: University Press).

[9] Dent, M. (1995). 'Ethnicity and Territorial Politics in Nigeria,' in G. Smith (ed.) Federalism: The Multiethnic Challenge (London: Longman).

[10] Ekekwe, E. (1986). Class and State in Nigeria. Ikeja: Longman Nigeria Ltd.

[11] Elaigwu, J.I. (1994). Autonomy of the Commune: Federal and Local Governance in Nigeria. Abuja: National Council on Intergovernmental Relations. 
[12] Elaigwu, J.I. (1994). 'Ethnicity and the Federal Option in Africa', The Nigerian Journal of Federalism, 1 (1).

[13] Elaigwu, J.I. (1978. 'Federal-State Relations in Nigeria's New Federalism: A Review of the Draft Constitution', in S. Kumo and A. Aliyu (eds.) Issues in the Nigerian Draft Constitution (Zaria: Baraka, Press Limited).

[14] Elaigwu, J.I. (1996). 'Military Rule and Federalism in Nigeria,' in J.I. Elaigwu and R.A. Akindele (eds.) Foundations of Nigerian Federalism: 1960-1995 (Abuja: National Council on Intergovernmental Relations).

[15] Elaigwu, J.I. (1983). 'Sub-national States and the Future of Federalism in Nigeria,' The Nigerian Journal of Political Economy, I (2).

[16] Elaigwu, J.I. (1985). 'The Military and Political Engineering in Nigeria (1966-79): An Overview,' in J.F. Ade Ajayi and B. Ikara (eds.) Evolution of Political Culture in Nigeria (Ibadan: University Press Limited).

[17] Elaigwu, J.I. (1979). 'The Military and State-Building: Federal-State Relations in Nigeria's Military Federalism, 1966-76', in A.B. Akinyemi et.al. (eds.) Readings on Federalism (Ibadan: University Press).

[18] Eleazu, U.O. (1977). Federalism and Nation-Building: The Nigerian Experience, 1954-1964. Devon: Arshur H. Stockwell Ltd.

[19] Ellah, F.J. (1983). Nigeria and States Creation. Port Harcourt: J.W. Ellah, Sons \&Co. Ltd.

[20] Faruk, U. (1992). The Struggle of the National Association for the Creation of More States. Zaria: The Northern Nigerian Publishing Company Limited.

[21] Gana, A.T. (1987). 'The Politics and Economics of State Creation in Nigeria,' Nigerian Journal of Policy and Strategy, 2 (1).

[22] Jega, A.M. (1999). 'The Nigerian Federal System: Problems and Prospects,' in L.R. Basta et.al. (eds.) Federalism and Decentralization in Africa: The Multicultural Challenge (Fribourg Suisse: Institut de federalismé).

[23] Jinadu, A.L. (1979). 'A Note on the Theory of Federalism,' in Akinyemi et.al. (eds.) Readings on Federalism (Ibadan: University Press).

[24] Kotze, H. (1994). 'Federalism: The State of the debate in South Africa,' The Nigerian Journal of Federalism, (1-2).

[25] Kumo, S. (1994). 'The Constitutional Conference: A Proposal for a Proper Federal System,' in A. Mahadi et.al (eds.). Nigeria: The State of the Nation and the Way Forward (Proceedings of the National Workshop on Organised by Arewa House, Kaduna, Centre for Historical Documentation and Research of the Ahmadu Bello University, Zaria.

[26] Nnoli, O. (1978). Ethnic Politics in Nigeria. Enugu: Fourth Dimension Publishers.

[27] Nwabueze B.O. (1983). Federalism in Nigeria under the Presidential Constitution. London: Sweet \& Maxwell.

[28] Odenigwe, G.A. (1977). 'The Constitutional Development of Nigeria: The Origins of Federalism: 1862-1954,' Ph.D Thesis, Clark University, Worcester, Massachusetts.

[29] Osaghae, E.E. (1985). 'Political Parties, the Creation of More States and Federal Stability in Nigeria,' in J.A. Atanda and A.Y. Aliyu (eds.) proceedings of the National Conference on Nigeria Since Independence. $\operatorname{xxx}(1)$.

[30] Osuntokun, J. (1979). 'The Historical Background of Nigerian Federalism,' in A.B. Akinyemi et.al. (eds.) Readings on Federalism (Ibadan: University Press).

[31] Report of the Political Bureau, Abuja: Directorate for Social Mobilization (MAMSER) Council Secretariat, 1986.

[32] Shagari, S. (2001). Beckoned to Serve. Ibadan: Heinemann Educational Books (Nigeria, Plc).

[33] Shastri, S. (2001). 'Changing Contours of Comparative Federalism: Understanding the Indian Experience,' paper presented on $9^{\text {th }}$ October at a seminar organized by the Department of Political Science, Usmanu Danfodiyo University, Sokoto, Nigeria.

[34] Smith, B. (1987). 'Federal-State Relations in Nigeria,' African Affairs 80 (320).

[35] Smith, G. (1995). 'Mapping the Federal Condition: Ideology, Political Practice and Social Justice,' in G. Smith (ed.) Federalism: The Multicultural Challenge (New York: Longman).

[36] Suberu, R.T. (1994). 'Recent Demands for New States in Nigeria,' The Nigerian Journal of Federalism, 1 (2).

[37] Suberu, R.T. (1998). 'States' Creation and the Political Economy of Nigerian Federalism,' in K. Amuwo et.al. (eds.) Federalism and Political Restructuring in Nigeria (Ibadan: Spectrum Books Limited). 
[38] Tagowa, W.N. (1994). 'The Structural Transformation of Nigeria's Federal compact and Nationbuilding,' The Nigerian Journal of Federalism, 1 (2).

[39] Takaya, B.J. (1996). 'The Structure of Conflict in Nigerian Federalism,' in J.I. Elaigwu and R.A. Akindele (eds.) Foundations of Nigerian Federalism: 1960-1995 (Abuja: National Council on Intergovernmental Relations).

[40] Tamuno, T.N. (1970). 'Separatist Agitations in Nigeria since 1914', Journal of Modern African Studies, $\operatorname{xxx}(1)$.

[41] Ukwu, U.I. (1987). 'Introduction' in Ukwu, U.I. (ed.) Federal Character and National Integration in Nigeria (Kuru: National Institute for Policy and Strategic Studies).

[42] Watts, R.L. (1970). Administration in Federal Systems. London: Hutchinson Educational Ltd.

[43] Watts, R.L. (1996). Comparing Federal Systems in the 1990s. Canada: Institute of Intergovernmental Relations.

[44] Wheare, K.C. (1964). Federal Government. London: Oxford University Press.

[45] Worvall, D.J. (1965). 'Nigerian Federalism: Its Genesis and Development', Ph.D Thesis, Cornell University.

[46] Yahaya, A.D. (1978). 'The Creation of States', in K. Panter-Brick (ed.) Soldiers and Oil: The Political Transformation of Nigeria (London: Frank Cass).

[47] Yaqub, N.O. (1997). 'State Creation and the Federal Principle,' Constitutions and Federalism (Proceedings of the Conference on Constitutions and Federalism, held at the University of Lagos, Nigeria, 23-25 April, 1996. 